\title{
The role of acid inhibition in Helicobacter pylori eradication
}

\section{[version 1; peer review: 3 approved]}

\author{
David R. Scott 1 , , George Sachs 1,2,4, Elizabeth A. Marcus 3,4 \\ ${ }^{1}$ Department of Physiology, David Greffen School of Medicine at UCLA, Los Angeles, CA, 90095, USA \\ 2Department of Medicine, David Greffen School of Medicine at UCLA, Los Angeles, CA, 90095, USA \\ ${ }^{3}$ Department of Pediatrics, David Greffen School of Medicine at UCLA, Los Angeles, CA, 90095, USA \\ 4VA Greater Los Angeles Healthcare System, Los Angeles, CA, 90073, USA
}

V1 First published: 19 Jul 2016, 5(F1000 Faculty Rev):1747

https://doi.org/10.12688/f1000research.8598.1

Latest published: 19 Jul 2016, 5(F1000 Faculty Rev):1747

https://doi.org/10.12688/f1000research.8598.1

\section{Abstract}

Infection of the stomach by the gastric pathogen Helicobacter pylori results in chronic active gastritis and leads to the development of gastric and duodenal ulcer disease and gastric adenocarcinoma. Eradication of $H$. pylori infection improves or resolves the associated pathology. Current treatments of $H$. pylori infection rely on acid suppression in combination with at least two antibiotics. The role of acid suppression in eradication therapy has been variously attributed to antibacterial activity of proton pump inhibitors directly or through inhibition of urease activity or increased stability and activity of antibiotics. Here we discuss the effect of acid suppression on enhanced replicative capacity of $H$. pylori to permit the bactericidal activity of growth-dependent antibiotics. The future of eradication therapy will rely on improvement of acid inhibition along with current antibiotics or the development of novel compounds targeting the organism's ability to survive in acid.

\section{Keywords}

Helicobacter pylori, gastritis, gastric, pathogen, stomach, infection

\section{Open Peer Review}

Approval Status

1

2

3

version 1

19 Jul 2016

Faculty Reviews are review articles written by the prestigious Members of Faculty Opinions. The articles are commissioned and peer reviewed before publication to ensure that the final, published version is comprehensive and accessible. The reviewers who approved the final version are listed with their names and affiliations.

1. Nayoung Kim, Seoul National University Bundang Hospital, Gyeonggi Province, South Korea

2. Hidekazu Suzuki, Keio University, Tokyo, Japan

3. Yoshio Yamaoka (D), Michael E DeBakey VA Medical Center, Houston, USA

Any comments on the article can be found at the end of the article. 
Corresponding author: David R. Scott (dscott@ucla.edu)

Competing interests: The authors declare that they have no competing interests.

Grant information: The authors are supported by K08DK100661 (Elizabeth A. Marcus), UCLA CDI (Elizabeth A. Marcus), USVA 2I01BX001006 (George Sachs), R01DK105156-01(George Sachs).

The funders had no role in study design, data collection and analysis, decision to publish, or preparation of the manuscript.

Copyright: ( 2016 Scott DR et al. This is an open access article distributed under the terms of the Creative Commons Attribution License, which permits unrestricted use, distribution, and reproduction in any medium, provided the original work is properly cited.

How to cite this article: Scott DR, Sachs G and Marcus EA. The role of acid inhibition in Helicobacter pylori eradication [version 1; peer review: 3 approved] F1000Research 2016, 5(F1000 Faculty Rev):1747 https://doi.org/10.12688/f1000research.8598.1

First published: 19 Jul 2016, 5(F1000 Faculty Rev):1747 https://doi.org/10.12688/f1000research.8598.1 


\section{Introduction}

Infection of the stomach by the gastric pathogen Helicobacter pylori results in chronic active gastritis and leads to the development of gastric and duodenal ulcer disease, gastric adenocarcinoma, or mucosa-associated lymphoid tissue (MALT) lymphoma. Eradication of $H$. pylori infection improves or resolves the associated pathology, leads to ulcer healing rates of $>90 \%$, and is effective in preventing the recurrence of bleeding ${ }^{1-3}$. Low-grade MALT lymphoma can be treated by eradication of $H$. pylori ${ }^{4-6}$. However, success rates of standard therapy regimens, typically including acid suppression and multiple antibiotics, have fallen below the acceptable level of $80 \%$ in many parts of the world ${ }^{7}$. The reason for the decline in treatment success is multifactorial, involving issues such as antibiotic resistance, patient compliance, level of acid suppression, and host and bacterial factors that alter the efficacy of treatment ${ }^{8}$.

Contemporary therapies for the treatment of $H$. pylori infection rely on acid suppression in combination with at least two antibiotics. Inhibition of the gastric $\mathrm{H}^{+}, \mathrm{K}^{+}$-ATPase, the final step in the acid secretion pathway, by proton pump inhibitors (PPIs) was initially included in eradication regimens to aid in symptom relief in patients suffering from peptic ulcer disease. However, it was found that PPIs and antibiotics act synergistically in eradicating $H$. pylori and acid inhibitors have been included in successful eradication treatments ever since. This raises the question of why inhibition of acid secretion is required. One suggestion is that PPIs have antibacterial properties. In vitro, the PPIs lansoprazole and omeprazole were shown to have antimicrobial properties that were unique to $H$. pylori as determined by the agar dilution method at neutral $\mathrm{pH}^{9}$. However, the antibacterial effect was seen only at industrial PPI concentrations $(100 \mu \mathrm{g} / \mathrm{ml})$ and only after 24 hours. The antibacterial effect of lansoprazole was attributed uniquely to the inhibition of $H$. pylori urease ${ }^{10}$. However, it was later shown that the in vitro effect of PPIs on the reduction in $H$. pylori survival was independent of urease activity and reduction in survival in the presence of PPIs was not unique to $H$. pylori ${ }^{11}$. Therefore, these findings, taken together, indicate it is unlikely that direct killing of the bacterium by PPIs contributes to the in vivo mechanism of PPI/ antibiotic synergy.

Another possible mechanism for PPI/antibiotic synergy in H. pylori eradication is that antibiotics are more stable and have higher activity at higher gastric pHs afforded by PPIs. In vitro, the antibacterial activity against $H$. pylori of both the macrolide and the quinolone antibiotics was inversely proportional to $\mathrm{pH}^{12}$. The $\mathrm{MIC}_{90}$ for the beta-lactam ampicillin was $2 \mu \mathrm{g} / \mathrm{ml}, 0.5 \mu \mathrm{g} / \mathrm{ml}$, and $0.25 \mu \mathrm{g} / \mathrm{ml}$ at $\mathrm{pH}$ 5.7-6.0, $\mathrm{pH} 7.4$, and $\mathrm{pH} 7.8-8.0$, respectively. On the other hand, the antibacterial activity against $H$. pylori by metronidazole was independent of $\mathrm{pH}$ down to at least $\mathrm{pH}$ 5.7.

\section{Acid acclimation}

H. pylori colonizes an acidic niche in the human stomach ${ }^{13}$. However, H. pylori is bioenergetically a neutralophile, able to survive at $\mathrm{pH} 4-8$ and grow at $\mathrm{pH} 6-8^{14}$ and is slow growing, with a doubling time of 4-6 hours, in contrast to 20 minutes for Escherichia coli. H. pylori is able to not only survive but also flourish in the highly acidic gastric environment through the mechanism of acid acclimation. The main feature of acid acclimation is the ability to maintain periplasmic $\mathrm{pH}$ close to neutrality in the presence of $\mathrm{acid}^{15}$. Acid acclimation is distinct from the acid resistance mechanisms of other bacteria that moderately elevate cytoplasmic $\mathrm{pH}$ to maintain viability but not growth in acid ${ }^{16}$. Acid acclimation by $H$. pylori is dependent on urease, a neutral-pHoptimum cytoplasmic-localized enzyme, and a proton gated urea channel, UreI ${ }^{15,17,18}$. Additionally, a periplasmic-localized $\alpha$-carbonic anhydrase enzyme also contributes to periplasmic buffering by catalyzing the conversion of carbon dioxide produced by urease to bicarbonate ${ }^{15}$.

An understanding of acid acclimation and $H$. pylori bioenergetics is critical to successful treatment protocols. $H$. pylori is uniquely adapted to survive in the acidic environment of the stomach; however, since it is a neutralophile, only a small fraction of the bacteria will actually be dividing or growing in acid as compared to more neutral $\mathrm{pH}$. This is demonstrated in transcriptomal studies, where cell division and cell wall synthesis genes increase transcription at neutral $\mathrm{pH}$ as compared to acidic $\mathrm{pH}(\mathrm{pH} 4.5)^{19}$. The antibiotics amoxicillin and clarithromycin used for the eradication of $H$. pylori infection are dependent on bacterial growth and cell envelope synthesis and therefore will only be bactericidal to actively dividing bacteria ${ }^{19}$. Since $H$. pylori that are not dividing at the time of antibiotic administration will not be killed by the antibiotics, the small population of viable bacteria restore colonization of the stomach once the antibiotics are stopped.

It is likely, therefore, that elevation of gastric $\mathrm{pH}$ by acid blockers stimulates $H$. pylori growth and accounts for their synergism with antibiotics. However, the median intragastric $\mathrm{pH}$ achieved by PPIs, at recommended doses, does not achieve the sustained $\mathrm{pH}$ elevation required to mimic the bactericidal effect seen in in vitro studies $^{19,20}$. More effective inhibition of acid secretion would likely increase eradication rates with a single antibiotic such as amoxicillin, to which current resistance is $<1 \%$ in Europe ${ }^{21}$. However, amoxicillin resistance appears to be on the rise in Asia and Africa, so the antibiotic used for dual therapy should be based on geographical resistance rates ${ }^{22,23}$. Support for this concept is found in eradication studies of high-dose dual therapy (HDDT), slow PPI metabolizers, and novel potent acid inhibitors.

Various dual therapy eradication regimens with PPIs and amoxicillin have been studied for over 20 years, but consistency in results has not been established. Meta-analysis of dual therapy with omeprazole $20 \mathrm{mg}$ bis in die and amoxicillin $>2 \mathrm{~g}$ total daily suggested a $>80 \%$ eradication rate and hinted at the importance of acid suppression in these regimens. However eradication rates of $30-50 \%$ were seen with similar dual regimens in other studies ${ }^{24,25}$. In one study, it was shown that the time with $\mathrm{pH}$ above 4 and continuous periods with intragastric $\mathrm{pH}$ above 6 were significantly associated with successful treatment of $H$. pylori, indicating that profound acid suppression was responsible for improved eradication rates. Amoxicillin dosing frequency is also an important factor as well. Amoxicillin, unlike many other antibiotics used in $H$. pylori eradication regimens, is time dependent, not concentration dependent, so time above $\mathrm{MIC}_{50}$ is an important factor in efficacy $^{26,27}$. A regimen of four times daily rabeprazole $(20 \mathrm{mg})$ and 


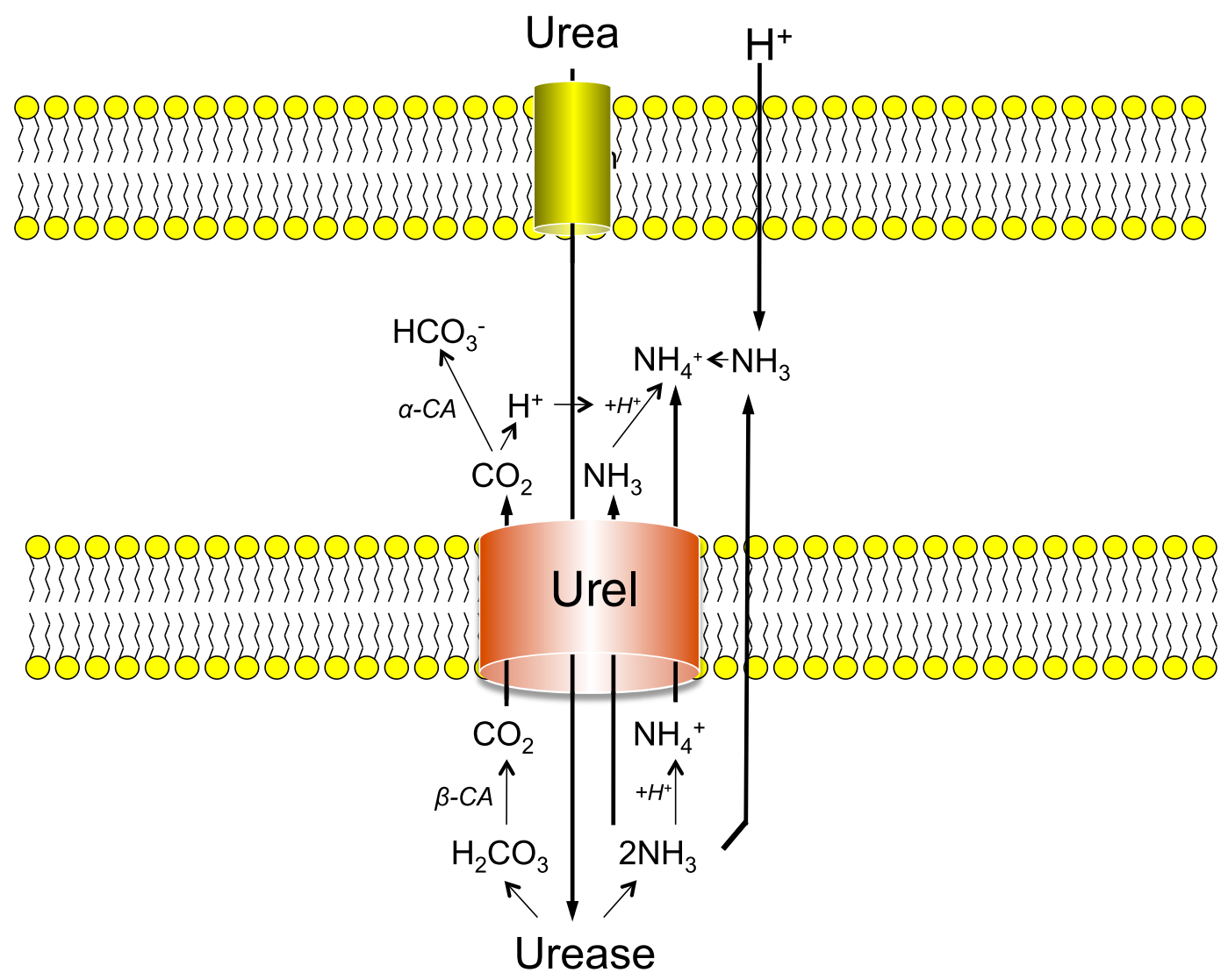

Figure 1. Acid acclimation by Helicobacter pylori. As the gastric lumen acidifies, the periplasmic $\mathrm{pH}$ of the Gram-negative pathogen $H$. pylori drops as well. Periplasmic acidification results in the protonation and opening of Urel, the proton gated urea channel in the inner membrane. With the opening of Urel, urea moves into the cytoplasm where it is hydrolyzed by urease, resulting in the production of carbonic acid and ammonia. Carbonic acid is converted to $\mathrm{CO}_{2}$ by the cytoplasmic $\beta$-carbonic anhydrase $(\beta-C A)$ enzyme. The two gasses diffuse through the membrane and through Urel into the periplasm, where $\mathrm{CO}_{2}$ is converted to bicarbonate by the periplasmic $\alpha$-carbonic anhydrase $(\alpha-C A)$ enzyme. The periplasm is then buffered to a $\mathrm{pH}$ of 6.1 , well within the $\mathrm{pH}$ range of survival for a neutralophile.

four times daily amoxicillin $(750 \mathrm{mg})$ for 14 days was superior to standard triple therapy, with eradication greater than $90 \%{ }^{28}$.

More evidence that profound acid inhibition is efficacious in H. pylori eradication comes from studies of PPI metabolism. PPIs are metabolized in the liver by cytochrome CYP2C1929, polymorphisms of which affect the pharmacokinetics and pharmacodynamics of the medication. The phenotypes of the CYP2C19 polymorphisms are rapid metabolizers (RM), intermediate metabolizers (IM), and poor metabolizers (PM) ${ }^{30}$. The plasma 'dwell time' of a single dose of omeprazole is directly correlated with the rate of metabolism among the different alleles with $P M>I M>R M$, which in turn affects the level of acid inhibition, again with $\mathrm{PM}>\mathrm{IM}>\mathrm{RM}$. The difference in the rate of metabolism influences the efficacy of $H$. pylori eradication, since the rate of eradication correlates well with the degree of acid inhibition; however, genotype is less of a factor as PPI doses are increased ${ }^{31}$. A standard $20 \mathrm{mg}$ dose of omeprazole in poor metabolizers produced $>90 \%$ eradication $^{28}$.

\section{PCABS: Potent acid inhibitors}

An alternative to high-dose PPI for eradication of H. pylori is the development of more potent acid suppressive agents. For example, vonoprazan, a potassium competitive acid blocker (PCAB), has the benefit of a more rapid and sustained acid inhibitory effect regardless of CYP2C19 genotype ${ }^{32}$. Vonoprazan is a weak base (pK 9.06) that accumulates in the parietal cell canaliculi at concentrations of up to $10^{8}$ fold higher than in the blood $(\mathrm{pH} \mathrm{7.4)})^{33}$. This inhibitor is highly selective for the gastric $\mathrm{H}^{+}, \mathrm{K}^{+}$-ATPase with a $\mathrm{K}_{\mathrm{i}}$ of $10 \mathrm{nM}$ and an $\mathrm{IC}_{50}$ of $17-19 \mathrm{nM}^{33}$. Binding is rapid, very slowly reversible, and reaches a plateau of inhibition within 200 seconds. The $t_{1 / 2}$ of dissociation is 4.7 and 7.5 hours for rabbit and hog proton pumps, respectively ${ }^{33}$. Taken together, these parameters indicate that vonoprazan has the potential for rapid, reversible, and longlasting inhibition of acid secretion when compared to the PPIs. The unique properties of vonoprazan combined with its greater degree of acid inhibition as compared with the PPIs, should provide greater efficacy in $H$. pylori eradication. Use of vonoprazan in place of PPIs has shown early promise in recent studies of Japanese 
populations, with an eradication rate of $70.2 \%$ using vonoprazan, amoxicillin, and clarithromycin as second-line therapy in patients who have failed first-line treatment with rabeprazole, amoxicillin, and clarithromycin and a $92.7 \%$ success rate of first-line therapy with vonoprazan, amoxicillin, and clarithromycin ${ }^{34,35}$.

\section{Conclusion}

H. pylori, being a neutralophile, replicates best at neutral $\mathrm{pH}$. The requirement for acid inhibition in $\mathrm{H}$. pylori eradication therapy is to raise the $\mathrm{pH}$ at the site of infection to allow growth of the organism and increase the efficacy of growth-dependent antibiotics. Increasing acid suppression by using higher doses of currently available PPIs or via development of novel acid inhibitors such as the PCAB vonoprazan or the use of antibiotics with low rates of antibacterial resistance will improve the rate of $H$. pylori eradication. The future of eradication therapy will depend on improvement of acid inhibition with current antibiotics or perhaps a totally new class of antibiotics. An exciting alternative, specific to $H$. pylori, would be compounds targeted to essential acid acclimation proteins such as UreI or carbonic anhydrase.

\section{Competing interests}

The authors declare that they have no competing interests.

\section{Grant information}

The authors are supported by K08DK100661 (Elizabeth A. Marcus), UCLA CDI (Elizabeth A. Marcus), USVA 2I01BX001006 (George Sachs), R01DK105156-01(George Sachs).

The funders had no role in study design, data collection and analysis, decision to publish, or preparation of the manuscript.
1. F Ford AC, Gurusamy KS, Delaney B, et al:: Eradication therapy for peptic ulcer disease in Helicobacter pylori-positive people. Cochrane Database Syst Rev. 2016; 4: CD003840. PubMed Abstract | Publisher Full Text | F1000 Recommendation

2. Gisbert JP, Khorrami S, Carballo F, et al:: H. pylori eradication therapy vs. antisecretory non-eradication therapy (with or without long-term maintenance antisecretory therapy) for the prevention of recurrent bleeding from peptic ulcer. Cochrane Database Syst Rev. 2004; (2): CD004062. PubMed Abstract | Publisher Full Text

3. Leodolter A, Kulig M, Brasch $\mathrm{H}$, et al.: A meta-analysis comparing eradication, healing and relapse rates in patients with Helicobacter pylori-associated gastric or duodenal ulcer. Aliment Pharmacol Ther. 2001; 15(12): 1949-58. PubMed Abstract | Publisher Full Text

4. Chen LT, Lin JT, Tai JJ, et al.: Long-term results of anti-Helicobacter pylori therapy in early-stage gastric high-grade transformed MALT lymphoma. J Nat Cancer Inst. 2005; 97(18): 1345-53.

PubMed Abstract | Publisher Full Text

5. Stathis A, Chini C, Bertoni F, et al:: Long-term outcome following Helicobacter pylori eradication in a retrospective study of 105 patients with localized gastric marginal zone B-cell lymphoma of MALT type. Ann Oncol. 2009; 20(6): 1086-93. PubMed Abstract | Publisher Full Text

6. Wotherspoon AC, Doglioni C, Diss TC, et al.: Regression of primary low-grade B-cell gastric lymphoma of mucosa-associated lymphoid tissue type after eradication of Helicobacter pylori. Lancet. 1993; 342(8871): 575-7. PubMed Abstract | Publisher Full Text

7. Graham DY, Lu H, Yamaoka Y: A report card to grade Helicobacter pylori therapy. Helicobacter. 2007; 12(4): 275-8. PubMed Abstract | Publisher Full Text

8. $\quad F$ Kim SY, Choi DJ, Chung JW: Antibiotic treatment for Helicobacter pylori: Is the end coming? World J Gastrointest Pharmacol Ther. 2015; 6(4): 183-98. PubMed Abstract | Publisher Full Text | Free Full Text | F1000 Recommendation

9. Iwahi $\mathrm{T}$, Satoh $\mathrm{H}, \mathrm{Nakao} \mathrm{M}$, et al.: Lansoprazole, a novel benzimidazole proton pump inhibitor, and its related compounds have selective activity against Helicobacter pylori. Antimicrob Agents Chemother. 1991; 35(3): 490-6. PubMed Abstract | Publisher Full Text | Free Full Text

10. Nagata K, Satoh H, Iwahi T, et al:: Potent inhibitory action of the gastric proton pump inhibitor lansoprazole against urease activity of Helicobacter pylori: unique action selective for $\boldsymbol{H}$. pylori cells. Antimicrob Agents Chemother. 1993; 37(4): 769-74.

PubMed Abstract | Publisher Full Text | Free Full Text

11. McGowan CC, Cover TL, Blaser MJ: The proton pump inhibitor omeprazole inhibits acid survival of Helicobacter pylori by a urease-independent mechanism. Gastroenterology 1994: 107(5): 1573-8. PubMed Abstract | Publisher Full Text

12. Grayson ML, Eliopoulos GM, Ferraro MJ, et al.: Effect of varying $\mathrm{pH}$ on the susceptibility of Campylobacter pylori to antimicrobial agents. Eur J Clin Microbiol Infect Dis. 1989; 8(10): 888-9.

PubMed Abstract | Publisher Full Text
13. Scott DR, Marcus EA, Wen $Y$, et al:: Gene expression in vivo shows that Helicobacter pylori colonizes an acidic niche on the gastric surface. Proc Natl Acad Sci U S A. 2007; 104(17): 7235-40.

PubMed Abstract | Publisher Full Text | Free Full Text

14. Meyer-Rosberg K, Scott DR, Rex D, et al:: The effect of environmental pH on the proton motive force of Helicobacter pylori. Gastroenterology. 1996; 111(4): 886-900.

PubMed Abstract | Publisher Full Text

15. Marcus EA, Moshfegh AP, Sachs G, et al:: The periplasmic alpha-carbonic anhydrase activity of Helicobacter pylori is essential for acid acclimation. J Bacteriol. 2005; 187(2): 729-38.

PubMed Abstract | Publisher Full Text | Free Full Text

16. Ma Z, Gong S, Richard H, et al.: GadE (YhiE) activates glutamate decarboxylasedependent acid resistance in Escherichia coli K-12. Mol Microbiol. 2003; 49(5): 1309-20.

PubMed Abstract | Publisher Full Text

17. Scott DR, Marcus EA, Weeks DL, et al.: Expression of the Helicobacter pylori urel gene is required for acidic $\mathrm{pH}$ activation of cytoplasmic urease. Infect Immun. 2000; 68(2): 470-7.

PubMed Abstract | Publisher Full Text | Free Full Text

18. Weeks DL, Eskandari S, Scott DR, et al:: $\mathbf{A} \mathbf{H}+-$ gated urea channel: the link between Helicobacter pylori urease and gastric colonization. Science. 2000; 287(5452): 482-5.

PubMed Abstract | Publisher Full Text

19. Marcus EA, Inatomi N, Nagami GT, et al:: The effects of varying acidity on Helicobacter pylori growth and the bactericidal efficacy of ampicillin. Aliment Pharmacol Ther. 2012; 36(10): 972-9. PubMed Abstract | Publisher Full Text | Free Full Text

20. Sugimoto M, Shirai N, Nishino M, et al.: Rabeprazole 10 mg q.d.s. decreases 24-h intragastric acidity significantly more than rabeprazole $20 \mathrm{mg}$ b.d. or 40 mg o.m., overcoming CYP2C19 genotype. Aliment Pharmacol Ther. 2012; 36(7): 627-34 PubMed Abstract | Publisher Full Text

21. F Thung I, Aramin H, Vavinskaya V, et al:: Review article: the global emergence of Helicobacter pylori antibiotic resistance. Aliment Pharmacol Ther. 2016; 43(4): 514-33.

PubMed Abstract | Publisher Full Text | F1000 Recommendation

22. Godoy AP, Ribeiro ML, Benvengo YH, et al: Analysis of antimicrobial susceptibility and virulence factors in Helicobacter pylori clinical isolates. BMC Gastroenterol. 2003; 3: 20 PubMed Abstract | Publisher Full Text | Free Full Text

23. F Yoon KH, Park SW, Lee SW, et al:: Clarithromycin-based standard triple therapy can still be effective for Helicobacter pylori eradication in some parts of the Korea. J Korean Med Sci. 2014; 29(9): 1240-6.

PubMed Abstract | Publisher Full Text | Free Full Text | F1000 Recommendation

24. Graham KS, Malaty H, el-Zimaity HM, et al:: Variability with omeprazoleamoxicillin combinations for treatment of Helicobacter pylori infection. Am J Gastroenterol. 1995; 90(9): 1415-8. PubMed Abstract 
Sjöstedt S, Sagar M, Lindberg G, et al.: Prolonged and profound acid inhibition is crucial in Helicobacter pylori treatment with a proton pump inhibitor combined with amoxicillin. Scand J Gastroenterol. 1998; 33(1): 39-43. PubMed Abstract | Publisher Full Text

26. MacGowan AP, Bowker KE: Continuous infusion of beta-lactam antibiotics. Clin Pharmacokinet. 1998; 35(5): 391-402. PubMed Abstract | Publisher Full Text

27. Midolo PD, Turnidge JD, Munckhof WJ: Is bactericidal activity of amoxicillin against Helicobacter pylori concentration dependent? Antimicrob Agents Chemother. 1996; 40(5): 1327-8. PubMed Abstract | Free Full Text

28. F Yang JC, Lin CJ, Wang HL: High-dose dual therapy is superior to standard first-line or rescue therapy for Helicobacter pylori infection. Clin Gastroenterol Hepatol. 2015; 13(5): 895-905.e5.

PubMed Abstract | Publisher Full Text | Free Full Text | F1000 Recommendation

29. Sakai T, Aoyama N, Kita T, et al.: CYP2C19 genotype and pharmacokinetics of three proton pump inhibitors in healthy subjects. Pharm Res. 2001; 18(6): 721-7.

PubMed Abstract | Publisher Full Text

30. Furuta T, Shirai N, Ohashi K, et al:: Therapeutic impact of CYP2C19 pharmacogenetics on proton pump inhibitor-based eradication therapy for Helicobacter pylori. Methods Find Exp Clin Pharmacol. 2003; 25(2): 131-43. PubMed Abstract | Publisher Full Text

31. Yang JC, Wang HL, Chern HD, et al.: Role of omeprazole dosage and cytochrome $\mathrm{P} 4502 \mathrm{C} 19$ genotype in patients receiving omeprazole-amoxicillin dual therapy for Helicobacter pylori eradication. Pharmacotherapy. 2011; 31(3): 227-38.

PubMed Abstract | Publisher Full Text

32. F Sakurai $\mathrm{Y}$, Mori $\mathrm{Y}$, Okamoto $\mathrm{H}$, et al.: Acid-inhibitory effects of vonoprazan $20 \mathrm{mg}$ compared with esomeprazole $20 \mathrm{mg}$ or rabeprazole $10 \mathrm{mg}$ in healthy adult male subjects--a randomised open-label cross-over study. Aliment Pharmacol Ther. 2015; 42(6): 719-30.

Pharmaco/ Ther. 2015; 42(6): 719-30.
PubMed Abstract | Publisher Full Text | F1000 Recommendation

33. Shin JM, Inatomi N, Munson $\mathrm{K}$, et al:: Characterization of a novel potassiumcompetitive acid blocker of the gastric H,K-ATPase, 1-[5-(2-fluorophenyl)-1(pyridin-3-ylsulfonyl)-1H-pyrrol-3-yl]- $N$-methylmethanamine monofumarate (TAK-438). J Pharmacol Exp Ther. 2011; 339(2): 412-20. (TAK-438). J Pharmacol Exp Ther. 2011; 339(2): 412-20.
PubMed Abstract | Publisher Full Text | Free Full Text

34. $\mathrm{F}$ Inaba $\mathrm{T}$, Iwamuro $\mathrm{M}$, Toyokawa $\mathrm{T}$, et al:: Letter: promising results of Helicobacter pylori eradication with vonoprazan-based triple therapy after failure of proton pump inhibitor-based triple therapy. Aliment Pharmacol Ther. 2016; 43(1): 179-80.

PubMed Abstract | Publisher Full Text | F1000 Recommendation

35. Murakami K, Sakurai Y, Shiino M, et al:: Tu1056 A Phase 3, Double-Blind Study of a Triple Therapy With TAK-438, Amoxicillin, and Clarithromycin As First Lin Eradication of $H$. pylori and a Triple Therapy With TAK-438, Amoxicillin, and Metronidazole As Second Line Eradication of $\boldsymbol{H}$. pylori. Gastroenterology. 2014; 146( 5, Supplement 1): S-740.

Publisher Full Text 


\section{Open Peer Review}

\section{Current Peer Review Status:}

\section{Editorial Note on the Review Process}

Faculty Reviews are review articles written by the prestigious Members of Faculty Opinions. The articles are commissioned and peer reviewed before publication to ensure that the final, published version is comprehensive and accessible. The reviewers who approved the final version are listed with their names and affiliations.

\section{The reviewers who approved this article are:}

\section{Version 1}

\section{Yoshio Yamaoka (iD)}

Molecular Pathogenesis Laboratory, Michael E DeBakey VA Medical Center, Houston, TX, 77030, USA Competing Interests: No competing interests were disclosed.

2. Hidekazu Suzuki Department of Internal Medicine, Keio University, Tokyo, 160-8582, Japan

Competing Interests: No competing interests were disclosed.

\section{Nayoung Kim}

Seoul National University Bundang Hospital, Gyeonggi Province, South Korea

Competing Interests: No competing interests were disclosed.

The benefits of publishing with F1000Research:

- Your article is published within days, with no editorial bias

- You can publish traditional articles, null/negative results, case reports, data notes and more

- The peer review process is transparent and collaborative

- Your article is indexed in PubMed after passing peer review

- Dedicated customer support at every stage

For pre-submission enquiries, contact research@f1000.com 